2 Miller A J, Texidor T A. Precordial catch. A neglected syndrome of precordial pain. JAMA 1955; 159: 1364-5.

3 Anyanwu C H, Adams P, Radley-Smith R, Yacoub M. Aortic homograft valve replacement for postendocarditis aortic incompetence in early childhood. Arch Dis Child 1978; 53: 759-60.

4 Matthews M B. The cardiovascular system. In: Macleod J, ed. Clinical examination, third edition. Edinburgh: Churchill Livingstone, 1973.

5 Sparrow M J, Bird E L. Precordial catch. A benign syndrome of chest pain in young persons. $N Z$ Med $J$ $1978 ; 88$ : 325-6.
${ }^{6}$ Bennett D H, Evans D W, Raj M V J. Echocardiographic left ventricular dimensions in pressure and volume overload. Their use in assessing aortic stenosis. Br Heart J 1975; 37: 971-7.

Correspondence to $\mathrm{Dr} \mathrm{D}$ Pickering, Department of Paediatrics, John Radcliffe Hospital, Headington, Oxford OX3 9DU.

Received 8 April 1980

\title{
Hypertension and segmental renal hypoplasia causing a syndrome of haemolysis and uraemia
}

\author{
R DUMAS, P BALDET, B ROLIN, AND R JEAN \\ Clinque des Maladies des Enfants, Hôpital Saint-Charles, Montpellier, France
}

SUMMARY An 11-year-old girl presented with acute renal failure and severe hypertension. The blood film showed thrombocytopenia, numerous fragmented red blood cells, and a reticulocyte count of $10 \%$. An intravenous pyelogram showed a small contracted left kidney, and plasma renin activity was increased in the left renal vein. Treatment with minoxidil and propanolol controlled the hypertension. After nephrectomy the hypertension resolved. Light microscopical examination of the left kidney showed a segmental renal hypoplasia. Malignant arterial hypertension can provoke a syndrome of haemolysis and uraemia in children. Aggressive lowering of blood pressure leads to an improvement in renal function.

Severe hypertension in haemolytic uraemic syndrome is common, and is often a complication of the renal disease. However, in adults, haemolysis and uraemia are present in some cases of malignant hypertension. ${ }^{1}$ This case report shows that this can be so in children too.

\section{Case report}

An 11-year-old girl presented with a history of polyuria, headaches, nausea, and vomiting for one year. Blood pressure (BP) had not been measured. Gross haematuria, pallor, and purpura had developed 3 days before admission. The day she was admitted BP was $250 / 130 \mathrm{mmHg}$. The liver was enlarged and there was bilateral oedema on the legs. Haematocrit was $23 \%$, haemoglobin $5 \mathrm{~g} / \mathrm{dl}$, white blood count $12.9 \times 10^{9} / 1$, platelets $10.0 \times 10^{9} / 1$. The blood film showed numerous fragmented red blood cells, and the reticulocyte count was $10 \%$. Urine analysis showed protein $(+++)$ and numerous red blood cells. Other values were as follows: blood urea $60 \mathrm{mg} / 100 \mathrm{ml}(9.9 \mathrm{mmol} / \mathrm{l})$ on admission rising to $185 \mathrm{mg} / 100 \mathrm{ml}(31 \mathrm{mmol} / \mathrm{l})$. Plasma creatinine level was $3 \mathrm{mg} / 100 \mathrm{ml}(265 \mu \mathrm{mol} / \mathrm{l})$, fibrinogen degradation products were between 25 and $40 \mathrm{mg} / \mathrm{ml}$. The C3 fraction of complement was $135 \mathrm{mg} / 100 \mathrm{ml}$ and the $\mathrm{C} 4$ was $49 \mathrm{mg} / 100 \mathrm{ml}$. Plasma renin activity, measured after the administration of $40 \mathrm{mg}$ furosemide and $20 \mathrm{mg}$ hydralazine, was found to be $708 \mathrm{ng} / \mathrm{ml}$ per hour. The normal value at this age, in the supine position and on a normal diet, is $3 \pm$ $2 \mathrm{ng} / \mathrm{ml}$ per hour in our laboratory. During the next 3 weeks the child received $80 \mathrm{mg}$ hydralazine $(4 \mathrm{mg} / \mathrm{kg})$ and $200 \mathrm{mg}$ acetobutolone $(10 \mathrm{mg} / \mathrm{kg})$ each day, and intravenous heparin at a dose of $5 \mathrm{mg} / \mathrm{kg}$ a day, for 7 days only. After this treatment BP, blood urea, reticulocyte count, and platelet count returned to normal. However, after a few days the blood pressure again rose to $160 / 130 \mathrm{mmHg}$, despite continuous antihypertensive treatment. One intravenous injection of $200 \mathrm{mg}$ diazoxide was given every day for 8 days. Treatment with minoxidil was started at a dose of $1 \mathrm{mg} / \mathrm{kg}$ a day with propanolol (40 mg daily) and furosemide (40 mg daily). After 3 days the BP had fallen to a normal level. The treatment was maintained at the same dose for 3 months. An intravenous pyelogram showed a small, contracted left kidney. The cystourethrogram was normal, without evidence of reflux. Left renal arteriography showed no evidence of stenosis, but 


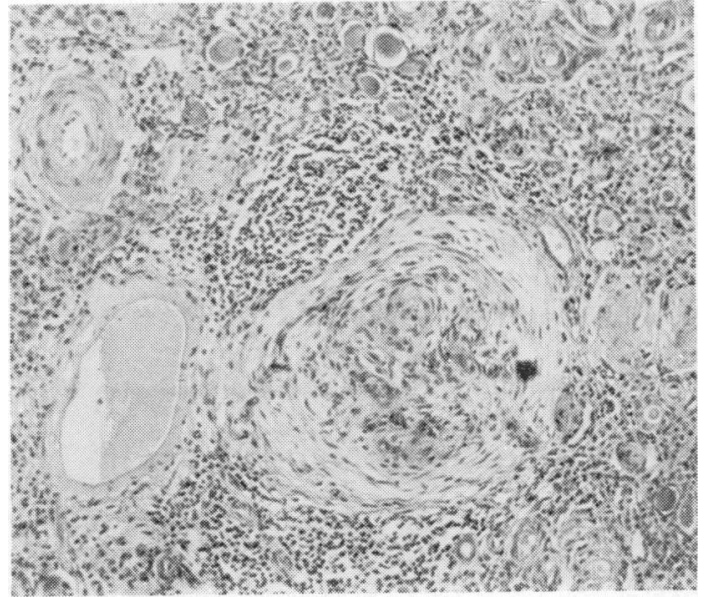

Figure Segmental renal hypoplasia in the left kidney, with dilated tubules and thickened blood vessels.

there was poor filling of vessels in the lower pole of the kidney. During treatment with hydralazine and acetobutolone, venous samples from right and left renal veins and from the inferior vena cava, below and above the renal veins, were taken. The plasma renin activity of venous blood from the inferior vena cava, below and above the renal veins was 4.8 and $7 \cdot 4 \mathrm{ng} / \mathrm{ml}$ per hour. In the left renal vein plasma renin activity was $14.6 \mathrm{ng} / \mathrm{ml}$ per hour, while it was $4.6 \mathrm{ng} / \mathrm{ml}$ per hour in the right. A right kidney biopsy was performed. On light microscopical examination focal and segmental glomerulosclerosis without pronounced vessel lesions could be seen. Because of the high level of plasma renin activity in the left renal vein, a left nephrectomy was performed. A small contracted kidney weighing $20 \mathrm{~g}$ and measuring $6 \times 2 \times 1 \mathrm{~cm}$ was removed. Light microscopical examination showed segmental areas of severe cortical and medullary abnormality. The affected segments contained a few sclerosed glomeruli, many atrophic and dilated tubules, and thickened blood vessels (Figure). After nephrectomy the hypertension resolved and the plasma renin level fell to $1 \mathrm{ng} / \mathrm{ml}$ per hour.

\section{Discussion}

The association between segmental renal hypoplasia (Ask-Upmark kidney) and hypertension has been known for many years. The pathogenesis of the hypertension in this disease is not perfectly understood. An abnormal renin secretion has been suggested in the course of this disease. ${ }^{2}$ Although the measurements were made after treatment had started in our patient, the renin level was three times the normal rate on the side of the diseased kidney. After nephrectomy the hypertension resolved and plasma renin activity fell to below the normal value. However, as is usual in the hypoplastic segment, no juxtaglomerular cells could be seen, thus raising the question of the origin of the secreted renin. Malignant arterial hypertension can provoke a syndrome of haemolysis and uraemia in adults, ${ }^{1}$ but this has not been reported in children. It has been suggested $^{34}$ that an increased BP would result in accumulation of fibrinogen and in the initiation of coagulation in the wall of the arteries. The fibrinoid vascular lesion might induce mechanical damage of the red blood cells and provoke a microangiopathic haemolytic anaemia. Furthermore, reversible acute renal failure can be the consequence of malignant hypertension. ${ }^{56}$ Aggressive lowering of BP commonly leads to an improvement in renal function. ${ }^{7}$ Minoxidil is a new vasodilator, and studies show that it is more effective than hydralazine. In this patient minoxidil combined with propanolol controlled hypertension. There was sodium and water retention and severe hypertrichosis. In a child with unilateral kidney disease, nephrectomy is undoubtedly the treatment of choice.

\section{Conclusion}

Renal segmental hypoplasia may be the cause of increased hypertension associated with haemolytic uraemic syndrome. Although treatment with minoxidil was effective for this type of hypertension, nephrectomy was performed because of side effects.

\section{References}

1 Linton A L, Gavras H, Gleadle R I. Microangiopathic haemolytic anaemia and the pathogenesis of malignant hypertension. Lancet 1969 ; i: 1277-82.

2 Godard G, Valloton M B, Broyer M. Plasma renin activity in segmental hypoplasia of the kidneys with hypertension. Nephron 1973; 11: 308-17.

3 Chester E M, Agamanolis D P, Banker B Q, Victor M. Hypertensive encephalopathy. A clinicopathologic study of 20 cases. Neurology 1978; 28: 928-39.

4 Heptinstall R H. Pathology of the kidney, second edition. Vol. 1. Boston: Little Brown, 1974: 121-62.

5 Eknoyan G, Siegel M B. Recovery from anuria due to malignant hypertension. JAMA 1971; 215: 1122-5.

6 Mandani B H, Lim V S, Mahurkar S D. Recovery from prolonged renal failure in patients with accelerated hypertension. N Engl J Med 1974; 291: 1343-4.

7 Luft F C, Bloch R, Szwed J J, Grim C M, Grim C E. Minoxidil treatment of malignant hypertension. Recovery of renal function. JAMA $1978 ; 240$ : 1985-7.

Correspondence to Dr R Dumas, Service de Pédiatrie (Prof. Jean), Hôpital Saint-Charles, 34059 Montpellier Cedex, France.

Received 2 January 1980 